\title{
HUBUNGAN KETERSEDIAAN DAN PEMANFAATAN AIR BERSIH DENGAN PENCEGAHAN DIARE DI DESA PERCUT KECAMATAN PERCUT SEI TUAN KABUPATEN DELI SERDANG TAHUN 2016
}

\author{
Andi Lala \\ Program Studi Prodi D-III Keperawatan, STIKes Indah Medan, Indonesia \\ Email: andilalamkm@gmail.com
}

\begin{abstract}
ABSTRAK
Pembangunan kesehatan memprioritaskan upaya peningkatan kesehatan dan pencegahan penyakit. Perilaku hidup bersih dan sehat dapat diterapkan dalam kehidupan sehari - hari demi mewujudkan lingkungan pemukiman yang bersih dan sehat. Maka yang menjadi permasalahan dalam penelitian ini adalah apakah ada hubungan ketersediaan dan pemanfaatan air bersih dengan pencegahan diare. Tujuan penelitian untuk mengetahui hubungan ketersediaan dan pemanfaatan air bersih dengan pencegahan diare di Desa Percut Kecamatan Percut Sei Tuan Kabupaten Deli Serdang tahun 2016. Desain penelitian cross sectional yaitu suatu penelitian untuk mempelajari suatu dinamika korelasi antara faktor-faktor resiko dengan efek, dan dengna suatu pendekatan, observasi ataupun dengan pengumpulan data pada suatu saat tertentu (point time approach). Dengan jumlah populasi yaitu seluruh ibu rumah tangga di Dusun 18 Desa Percut berjumlah 273 kepala keluarga. Sampel pada penelitian ini sebanyak 71 responden diambil secara Random Sampling. Analisis data menggunakan ujichi square. Kesimpulan pada penelitian ini adalah ketersediaan dan pemanfaatan air bersih mempunyai hubungan signifikan dengan pencegahan diare di Desa Percut Kecamatan Percut Sei Tuan Kabupaten Deli Serdang tahun 2016 dengan nilai p<0,05. Disarankan kepada Dinas Kesehatan Kabupaten Deli Serdang untuk meningkatkan program promosi kesehatan yang melibatkan masyarakat agar memiliki tanggung jawab bersama yang berdampak pada kemauan, kemampuan dan kemandirian untuk selalu berperilaku hidup sehat.
\end{abstract}

Kata Kunci : Ketersediaan, Pemanfaatan Air Bersih.

\section{ABSTRACT}

Health development prioritizes efforts to improve health and prevent disease. Clean and healthy living behavior can be applied in everyday life in order to create a clean and healthy residential environment. So the problem in this study is whether there is a relationship between the availability and utilization of clean water with diarrhea prevention. The research objective was to determine the relationship between the availability and use of clean water and the prevention of diarrhea in Percut Village, Percut Sei Tuan District, Deli Serdang Regency in 2016. The cross-sectional research design is a study to study a dynamic correlation between risk factors and effects, and with an approach, observation or by collecting data at a certain time (point time approach). With the total population, namely all housewives in Dusun 18, Percut Village, totaling 273 families. The sample in this study were 71 respondents who were taken by random sampling. Data analysis using Ujichi square. The conclusion of this study is the availability and use of clean water has a significant relationship with diarrhea prevention in Percut Village, Percut Sei Tuan District Deli Serdang Regency in 2016 with a p value <0.05. It is recommended to the Deli Serdang District Health Office to increase health promotion programs that involve the community so that they have shared responsibility which has an impact on the willingness, ability and independence to always behave in a healthy life.

Keywords : Availability, Utilization of Clean Water.

\section{PENDAHULUAN}

Sehat merupakan prasyarat agar hidup kita menjadi berarti, sejahtera, dan bahagia. Pembangunan kesehatan memprioritaskan upaya peningkatan kesehatan dan pencegahan penyakit. Adanya pembangunan kesehatan tersebut diharapkan kondisi masyarakat, bangsa dan negara dimasa mendatang dapat hidup dalam lingkungan sehat dan berperilaku hidup bersih dan sehat. Salah satu arah kebijakan untuk mencapai tujuan tersebut adalah adanya upaya mewujudkan 
lingkungan pemukiman yang bersih dan sehat.

Perilaku Hidup Bersih Dan Sehat (PHBS) dapat diterapkan dalam kehidupan sehari-hari seperti lingkungan rumah tangga, sekolah, dan tempat kerja. Perilaku hidup bersih dan sehat seseorang sangat berhubungan dengan peningkatkan derajat kesehatan individu, keluarga, masyarakat dan lingkungannya. Sehingga dengan berperilaku sehat dalam kehidupan sehari-hari akan menghindarkan kita dari berbagai penyakit terutama penyakit-penyakit infeksi seperti diare.

Diare merupakan kondisi yang ditandai dengan bertambahnya frekuensi defekasi (buang air besar) lebih dari biasanya (lebih dari 3 kali dalam sehari) disertai perubahan konsistensi tinja (menjadi lembek atau cair) dengan atau tanpa darah ataupun lendir. Jika tidak mendapat penanganan yang tepat, dapat menyebakan dehidrasi yang pada akhirnya dapat mengakibatkan kematian.

Untuk mencegah terjadinya diare maka air bersih harus diambil dari sumber yang terlindungi atau tidak terkontaminasi. Sumber air bersih harus jauh dari kandang ternak dan kakus paling sedikit sepuluh meter dari sumber air. Air harus ditampung dalam wadah yang bersih dan pengambilan air dalam wadah dengan menggunakan gayung yang bersih, dan untuk minum air harus di masak. Masyarakat yang terjangkau oleh penyediaan air bersih mempunyai resiko menderita diare lebih kecil bila dibandingkan dengan masyarakat yang tidak mendapatkan air besih.

Menurut (World Health Organization, 2014) sebanyak 4\% kematian di seluruh dunia disebabkan oleh diare. Dan membunuh 2,2 juta orang tiap tahunnya. Kebanyakan dari mereka adalah anak-anak. Angka kesakitan diare di Indonesia tahun 2015 mencapai 321/1000 penduduk. Persentase PHBS di Provinsi Sumatera Utara tahun 2015 berada pada angka $60,04 \%$. Persentase tertinggi di Kota Pematang Siantar sebesar 45,4\%, diikuti Kota Binjai sebesar 44,7\% dan Kota Sibolga sebesar 43,2\%. Persentase terendah di Kabupaten Nias sebesar 3,7\%, Humbang Hasundutan sebesar 5,2\% dan Pakpak Barat 5,4\%.

Persentase rumah tangga ber-PHBS Baik di Kabupaten Deli Serdang Tahun 2015 berada pada angka $28,7 \%$, dan rumah tangga ber-PHBS kurang baik sebesar 71,3\% Masih rendahnya rumah tangga ber-PHBS baik di Kabupaten Deli Serdang dikhawatirkan akan dapat menjadi pemicu munculnya berbagai masalah kesehatan terutama penyakit infeksi yang ditimbulkan oleh rendahnya perilaku hidup bersih dan sehat serta sarana sanitasi yang tidak memadai seperti diare, cacingan, sakit kulit, gizi buruk dan lain sebagainya.

Data Dinas Kesehatan Kabupaten Deli Serdang menunjukkan terjadi peningkatan jumlah kasus Diare dari tahun 2014 sebanyak 15.458 kasus dan tahun 2015 sebanyak 17.453 .

Jumlah kasus Diare Tahun 2015 di wilayah kerja Puskesmas Tanjung Rejo Kecamatan Percut Sei Tuan adalah yang tertinggi dibanding wilayah puskesmas lainnya yaitu sebanyak 3.541 kasus, kejadian kasus diare tertinggi terdapat di Desa Percut yaitu sebanyak 696 kasus.

Menurut penelitian yang berkaitan dengan hidup bersih menyatakan bahwa tugas keluarga dalam penerapan perilaku hidup bersih dan sehat di Desa Pematang Lalang Kecamatan Percut Sei Tuan ini terkategori cukup dikaitkan dengan media informasi yang masih kurang ditandai dengan terbatasnya sarana pelayanan kesehatan dan jarak yang cukup jauh dari lokasi masyarakat yang berpusat di Puskesmas Tanjung Rejo untuk dipergunakan oleh desa-desa yang ada di kecamatan ini (Manurung, 2019).

Menurut penelitian lain yang berjudul hubungan antara sumber air dengan kejadian diare pada warga Kampung Baru Ngagelrejo Wonokromo Surabaya menyatakan hasil penelitian menunjukkan bahwa ada hubungan tingkat sedang antara sumber air dengan kejadian diare pada warga Kampung Baru Ngagelrejo Wonokromo Surabaya (Harsa, 2019).

Berdasarkan hasil survei yang dilakukan di Desa Percut Kecamatan Percut Sei Tuan pada bulan Nopember 2015 dengan mengumpulkan data laporan Puskesmas Tanjung Rejo diperoleh gambaran bahwa cakupan rumah tangga yang ber perilaku hidup bersih dan sehat sebanyak 22,78\%, dan jumlah kasus Diare di Desa Percut Kecamatan Percut Sei Tuan sebanyak 696 kasus. Hasil pengamatan juga menunjukkan ketersediaan air bersih diwilayah tersebut 
sangat terbatas, sehingga masyarakat kebanyakan menggunakan air sungai sebagai pasokan air untuk kebutuhan sehari-hari.

Selain itu kondisi jamban pribadi masyarakat masih jauh dari kondisi jamban sehat, mayoritas masyarakat memiliki jamban jenis cemplung yang dibuat di belakang rumah dan langsung terhubung dengan aliran sungai Percut Sei Tuan.Sebagai sumber air minum masyarakat di wilayah tersebut hanya terdapat 2 buah sumur bor (ledeng) yang dibangun sebagai fasilitas umum untuk digunakan secara bersama, sedangkan sebahagian kecil warga memanfaatkan air isi ulang sebagai sumber air minum.

Tujuan penelitian ini adalah untuk mengetahui hubungan ketersediaan dan pemanfaatan air bersih/dengan pencegahan diare di Desa Percut Kecamatan Percut Sei Tuan Kabupaten Deli Serdang tahun 2016.

\section{METODE}

Penelitian ini adalah penelitian survei eksplanatori dengan pendekatan cross sectional yaitu suatu penelitian untuk mempelajari suatu dinamika korelasi antara faktor-faktor resiko dengan efek, dan dengna suatu pendekatan, observasi ataupun dengan pengumpulan data pada suatu saat tertentu (point time approach) (notoatmodjo, 2002). Penelitian ini dilakukan di Dusun 18 Desa Percut Kecamatan Percut Sei Tuan Kabupaten Deli Serdang yang terletak di kawasan Daerah Aliran Sungai Pecut Sei Tuan dari bulan Januari-Mei 2016.

Populasi adalah seluruh ibu rumah tangga yang berdomisili di Dusun 18 Desa Percut Kecamatan Percut Sei Tuan Kabupaten Deli Serdang yang berjumlah 273 kepala keluarga. Pengambilan sampel dilakukan secara secara acak (Simple Random Sampling) sebanyak 71 orang ibu rumah tangga. Instrumen penelitian berupa kuesioner dan dokumen yang berhubungan dengan penelitian. Analisis data dilakukan secara chi square. Uji ini digunakan untuk mengetahui ketergantungan dan homogenitas dua prosedur, yang meliputi perbandingan frekuensi yang teramati dan frekuensi yang diharapkan, jika Ho yang ditetapkan adalah benar (Wahana Komputer, 2009).

\section{HASIL DAN PEMBAHASAN}

\section{A. Karakteristik Responden}

Karakteristik individu dalam penelitian ini adalah keseluruhan data dan informasi responden yang terdiri dari umur, tingkat pendidikan, jenis pekerjaan, yang di sajikan dalam tabel 1 berikut:

Tabel 1. Karakteristik Responden

\begin{tabular}{lll}
\hline \multirow{2}{*}{ Karakteristik Responden } & \multicolumn{2}{l}{ Jumlah } \\
\cline { 2 - 3 } 1. Umur & n & \% \\
17-35 Tahun & & \\
$36-45$ Tahun & 10 & 85,9 \\
Total & 71 & 14,1 \\
2. Pendidikan & & \\
Pendidikan Dasar & 9 & 12,7 \\
Pendidikan Menengah & 48 & 67,6 \\
Pendidikan Tinggi & 14 & 19,7 \\
Total & 71 & 100 \\
\hline 3. Pekerjaan & & \\
Ibu Rumah Tangga & 27 & 38,0 \\
Petani & 9 & 12,7 \\
Wiraswasta & 26 & 36,6 \\
PNS/TNI/POLRI & 9 & 12,7 \\
Total & 71 & 100 \\
\hline
\end{tabular}

Berdasarkan tabel 1 di atas menunjukkan bahwa mayoritas umur responden berumur 17-35 tahun yaitu sebanyak 61 orang $(85,9 \%)$. Tingkat pendidikan responden, mayoritas sebanyak 48 orang $(67,6 \%)$ berpendidikan menengah. Dan jenis pekerjaan, mayoritas sebanyak 27 orang $(38,0 \%)$ bekerja sebagai ibu rumah tangga.

\section{B. Analisis Univariat}

Hasil penelitian setiap pertanyaan kepada responden sebagaimana di jabarkan pada tabel 2 berikut.

Tabel 2. Distribusi Frekuensi Ketersediaan Air Bersih Responden di Desa Percut Sei Tuan Kabupaten Deli Serdang Tahun 2016

\begin{tabular}{|c|c|c|c|c|c|c|c|}
\hline \multirow{3}{*}{ No. } & \multirow{3}{*}{ Pertanyaan } & \multicolumn{4}{|c|}{ Jawaban } & \multirow{2}{*}{\multicolumn{2}{|c|}{ Total }} \\
\hline & & \multicolumn{2}{|c|}{ Ya } & \multicolumn{2}{|c|}{ Tidak } & & \\
\hline & & $\mathbf{n}$ & $\%$ & $\mathbf{n}$ & $\%$ & $\mathbf{N}$ & $\%$ \\
\hline 1. & $\begin{array}{l}\text { Apakah anda memiliki tempat penampungan air } \\
\text { dirumah? }\end{array}$ & 64 & 90,1 & 7 & 9,9 & 71 & 100 \\
\hline
\end{tabular}




\begin{tabular}{|c|c|c|c|c|c|c|c|}
\hline 2. & $\begin{array}{l}\text { Apakah wadah penampungan penampungan air } \\
\text { anda terbuat dari bahan yang kedap air? }\end{array}$ & 31 & 43,7 & 40 & 56,3 & 71 & 100 \\
\hline 3. & $\begin{array}{l}\text { Apakah tempat penampungan air anda dengan } \\
\text { wadah tertutup? }\end{array}$ & 33 & 46,5 & 38 & 53,5 & 71 & 100 \\
\hline 4. & $\begin{array}{l}\text { Apakah sumber air yang anda konsumsi tidak } \\
\text { berwarna, berasa dan berbau? }\end{array}$ & 49 & 69,0 & 22 & 31,0 & 71 & 100 \\
\hline 5. & $\begin{array}{l}\text { Apakah sumber air yang anda gunakan } \\
\text { memiliki jarak > } 10 \text { meter dari sarana } \\
\text { pembuangan tinja/ kotoran? }\end{array}$ & 37 & 52,1 & 34 & 47,9 & 71 & 100 \\
\hline
\end{tabular}

Berdasarkan tabel 2 mayoritas $90,1 \%$ responden manyatakan memiliki tempat penampungan air bersih dirumah. Mayoritas sebanyak $56,3 \%$ responden menyatakan tidak memiliki wadah penampungan penampungan air bersih anda terbuat dari bahan yang kedap air. Mayoritas sebanyak 53,5\% responden menyatakan tidak memiliki tempat penampungan air bersih anda dengan wadah tertutup. Mayoritas sebanyak 69,0\% responden menyatakan sumber air yang dikonsumsi tidak berwarna, berasa dan berbau, dan sebanyak $52,1 \%$ responden menyatakan sumber air yang anda gunakan memiliki jarak lebih dari 10 meter dari sarana pembuangan tinja/kotoran. Keseluruhan hasil dari pertanyaan Ketersediaan kemudian di tabulasi dalam bentuk distribusi frekuensi.

Setelah dilakukan pengkategorian maka diketahui bahwa mayoritas kondisi Ketersediaan air responden adalah kurang baik yaitu sebanyak 40 responden $(56,3 \%)$. Secara lebih rinci dapat dilihat pada tabel 3 berikut:

Tabel 3. Distribusi Kategori Ketersediaan Responden di Desa Percut Sei Tuan

Kabupaten Deli Serdang Tahun 2016

\begin{tabular}{|c|c|c|c|}
\hline \multirow{2}{*}{ No } & \multirow{2}{*}{ Ketersediaan } & \multicolumn{2}{|r|}{ Jumlah } \\
\hline & & $\mathbf{n}$ & Persentase (\%) \\
\hline 1. & Baik & 31 & 43,7 \\
\hline & Kurang Baik & 40 & 56,3 \\
\hline Tot: & & 71 & 100 \\
\hline
\end{tabular}

Pemanfaatan air bersih responden diukur berdasarkan 10 pertanyaan dengan opsi jawaban Selalu, Kadang-kadang dan Jarang tentang tindakan sehari-hari responden menggunakan air. Hasil pertanyaan dari setiap responden sebagaimana di jabarkan pada tabel 4 berikut.

Tabel 4. Distribusi Frekuensi Pemanfaatan Air Bersih di Desa Percut Sei Tuan Kabupaten Deli Serdang Tahun 2016

\begin{tabular}{|c|c|c|c|c|c|c|c|c|c|}
\hline \multirow{3}{*}{ No. } & \multirow{3}{*}{ Pertanyaan } & \multicolumn{6}{|c|}{ Jawaban } & \multirow{2}{*}{\multicolumn{2}{|c|}{ Total }} \\
\hline & & \multicolumn{2}{|c|}{ Selalu } & \multicolumn{2}{|c|}{ Kadang } & \multicolumn{2}{|c|}{ Jarang } & & \\
\hline & & $\mathbf{n}$ & $\%$ & $\mathbf{n}$ & $\%$ & $\mathbf{n}$ & $\%$ & $\mathbf{N}$ & $\%$ \\
\hline 1. & $\begin{array}{l}\text { Apakah ibu selalu menggunakan air bersih } \\
\text { untuk keperluan memasak? }\end{array}$ & 33 & 46,5 & 38 & 53,5 & 0 & 0,0 & 71 & 100 \\
\hline 2. & $\begin{array}{l}\text { Apakah ibu selalu menggunakan air } \\
\text { bersih untuk mencuci botol susu anak? }\end{array}$ & 23 & 32,4 & 48 & 67,6 & 0 & 0,0 & 71 & 100 \\
\hline 3. & $\begin{array}{l}\text { Apakah ibu selalu menggunakan air } \\
\text { bersih untuk mandi dan memandikan } \\
\text { anak? }\end{array}$ & 39 & 54,9 & 32 & 45,1 & 0 & 0,0 & 71 & 100 \\
\hline 4. & $\begin{array}{l}\text { Apakah ibu selalu menggunakan air } \\
\text { bersih untuk keperluan mencuci peralatan } \\
\text { dapur? }\end{array}$ & 21 & 29,6 & 28 & 39,4 & 22 & 31,0 & 71 & 100 \\
\hline 5. & $\begin{array}{l}\text { Apakah ibu selalu menggunakan air } \\
\text { bersih untuk keperluan mencuci bahan } \\
\text { makanan? }\end{array}$ & 24 & 33,8 & 31 & 43,7 & 16 & 22,5 & 71 & 100 \\
\hline 6. & $\begin{array}{l}\text { Apakah ibu selalu menggunakan air } \\
\text { bersih untuk keperluan mencuci pakaian? }\end{array}$ & 29 & 40,8 & 33 & 46,5 & 9 & 12,7 & 71 & 100 \\
\hline 7. & $\begin{array}{l}\text { Apakah ibu selalu menggunakan air } \\
\text { bersih untuk keperluan membersihkan } \\
\text { lantai rumah? }\end{array}$ & 24 & 33,8 & 33 & 46,5 & 14 & 19,7 & 71 & 100 \\
\hline
\end{tabular}




\begin{tabular}{lllllllll}
\hline 8. & $\begin{array}{l}\text { Apakah ibu selalu menggunakan air } \\
\text { bersih yang di masak untuk keperluan } \\
\text { konsumsi air minum di rumah? }\end{array}$ & 39,4 & 39 & 54,9 & 4 & 5,6 & 71 & 100 \\
\hline 9. & $\begin{array}{l}\text { Apakah ibu selalu menggunakan air } \\
\text { bersih saat mencuci tangan sebelum atau } \\
\text { sesudah makan? }\end{array}$ & 44,9 & 34 & 47,9 & 3 & 4,2 & 71 & 100 \\
\hline $\begin{array}{l}\text { Apakah saat membersihkan buang air } \\
\text { besar/kecil anak, ibu selalu menggunakan 22 } \\
\text { air? }\end{array}$ & 31,0 & 30 & 42,3 & 19 & 26,8 & 71 & 100 \\
\hline
\end{tabular}

Tabel 4 menjelaskan hasil penelitian sebanyak $53,5 \%$ mayoritas responden kadang -kadang menggunakan air untuk keperluan memasak, sebanyak $67,6 \%$ mayoritas responden kadang-kadang menggunakan air untuk mencuci botol susu anak, sebanyak $54,9 \%$ mayoritas responden selalu menggunakan air untuk mandi dan memandikan anak, sebanyak 39,4\% mayoritas responden kadang-kadang menggunakan air untuk keperluan mencuci peralatan dapur, sebanyak $43,7 \%$ mayoritas responden kadang-kadang menggunakan air untuk keperluan mencuci bahan makanan, sebanyak 46,5\% mayoritas responden menyatakan kadang-kadang menggunakan air untuk keperluan mencuci pakaian, sebanyak $46,5 \%$ mayoritas responden menyatakan kadang-kadang menggunakan air untuk keperluan membersihkan lantai rumah, sebanyak 54,9\% mayoritas responden menyatakan kadang-kadang menggunakan air yang di masak untuk keperluan konsumsi air minum di rumah, sebanyak $47,9 \%$ mayoritas responden menyatakan selalu menggunakan air saat mencuci tangan sebelum atau sesudah makan, dan sebanyak 42,3\% mayoritas responden menyatakan kadang-kadang membersihkan buang air besar/kecil anak, ibu selalu menggunakan air.

Keseluruhan hasil dari penilaian terhadap pemanfaatan air bersih responden di tabulasi dalam bentuk distribusi frekuensi. Setelah dilakukan pengkategorian maka diketahui bahwa mayoritas praktik cuci tangan pakai sabun responden adalah kurang baik yaitu sebanyak 42 responden $(59,2 \%)$. Secara lebih rinci dapat dilihat pada tabel 5 berikut.

Tabel 5. Distribusi Frekuensi Kategori Pemanfaatan Air Bersih di Desa Percut Sei Tuan Kabupaten Deli Serdang Tahun 2016

\begin{tabular}{ll|cc}
\hline \multirow{2}{*}{ No } & $\begin{array}{l}\text { Perilaku } \\
\text { Penggunaan air }\end{array}$ & \multicolumn{2}{c}{ Jumlah } \\
\cline { 2 - 3 } & N & Persentase (\%) \\
\hline 1. & Baik & 29 & 40.8 \\
\hline 2. & Kurang Baik & 42 & 59.2 \\
\hline & Total & $\mathbf{7 1}$ & $\mathbf{1 0 0}$ \\
\hline
\end{tabular}

\section{Analisis Bivariat}

\section{Hubungan Ketersediaan dengan Pemanfaatan Air Bersih}

Tabel 6 dibawah ini menggambarkan hasil tabulasi silang antara Ketersediaan dengan Pemanfaatan air bersih, diperoleh mayoritas responden yang memiliki Ketersediaan baik sebanyak 21 orang $(29,6 \%)$ bertindak dengan baik. Hasil penelitian juga menunjukkan mayoritas responden yang memiliki Ketersediaan kurang baik sebanyak sebanyak 32 orang $(45,1 \%)$ bertindak kurang baik. Hasil analisis juga menunjukkan Ketersediaan $(\mathrm{p}=0,001)$ berhubungan secara signifikan dengan tindakan Pemanfaatan air bersih karena nilai $p<0,05$, sebagaimana dapat dilihat pada tabel berikut.

Tabel 6. Tabulasi Silang Ketersediaan dengan Pemanfaatan Air Bersih di Desa Percut Kabupaten Deli Serdang Tahun 2016

\begin{tabular}{|c|c|c|c|c|c|c|c|c|}
\hline \multirow{3}{*}{ No. } & \multirow{3}{*}{ Ketersediaan } & \multicolumn{4}{|c|}{ Pemanfaatan Air Bersih } & \multirow{2}{*}{\multicolumn{2}{|c|}{ Total }} & \multirow{3}{*}{ Nilai p } \\
\hline & & \multicolumn{2}{|c|}{ Baik } & \multicolumn{2}{|c|}{ Kurang Baik } & & & \\
\hline & & $\mathbf{N}$ & $\%$ & $\mathbf{n}$ & $\%$ & $\mathbf{N}$ & $\%$ & \\
\hline 1. & Baik & 21 & 29,6 & 10 & 14,1 & 31 & 43,7 & \multirow{2}{*}{0,001} \\
\hline 2. & Kurang Baik & 8 & 11,2 & 32 & 45,1 & 40 & 56,3 & \\
\hline & Jumlah & 29 & 40,8 & 42 & 59,2 & 71 & 100 & \\
\hline
\end{tabular}




\section{KESIMPULAN}

Ketersediaan dan pemanfaatan air bersih mempunyai hubungan signifikan dengan pencegahan diare di Desa Percut Kecamatan Percut Sei Tuan Kabupaten Deli Serdang tahun 2016 dengan nilai $\mathrm{p}<0,05$.

\section{REFERENCES}

Depkes RI. Pedoman Pemberantasan Penyakit Diare Tahun 2010. [Dokumen Internet]. Jakarta. Tersedia dari: www.depkes.go.id. [diakses tanggal 18 Maret 2016].

Depkes RI. Buletin Jendela Epidemiologi Tahun 2014. [Dokumen Internet]. Jakarta. Tersedia dari: www.depkes.go.id/folder/view/01/struct ure-publikasi-pusdatin-buletin.html [diakses tanggal 18 Maret 2016].

Depkes RI. Permenkes Nomor 2269/PER/KEP/XI/ 2011, Pedoman Perilaku Hidup Bersih dan Sehat. [Dokumen Internet]. Jakarta. Tersedia dari: www.depkes.go.id. [diakses tanggal 10 Januari 2016].

Depkes RI. Profil Kesehatan Indonesia Tahun 2015. [Dokumen Internet]. Jakarta. Tersedia dari: www.depkes.go.id. [diakses tanggal 16 Oktober 2015].
Dinkes Deli Serdang. Profil Kesehatan Kabupaten Deli Serdang, Lubuk Pakam, 2015.

Dinkes Sumut. Profil Kesehatan Provinsi Sumatera Utara, Medan, 2015.

Kemenkes RI. Undang-Undang Nomor 36 Tahun 2009 tentang Kesehatan, Kementerian Kesehatan RI. Jakarta, 2009.

Notoatmodjo, S. 2002. Metodologi Penelitian Kesehatan. Jakarta: Rineka Cipta.

Puskesmas Tanjung Rejo. Profil Puskesmas Tanjung Rejo, Percut Sei Tuan. 2015.

Harsa, I. M. S. (2019). Hubungan Antara Sumber Air Dengan Kejadian Diare Padawarga Kampung Baru Ngagelrejo Wonokromo Surabaya. Journal of Agromedicine and Medical Sciences, 5(3), 124-129.

Manurung, N. (2019). Faktor-Faktor Yang Mempengaruhi Keluarga Dalam Penerapan Perilaku Hidup Bersih Dan Sehat Di Desa Pematang Lalang. Jurnal Ilmiah Keperawatan Imelda, 5(1), 1-4. http://jurnal.uimedan.ac.id/index.php/JU RNALKEPERAWATAN.

Wahana Komputer. (2009). SPSS 17 Untuk Pengolahan Data Statistik (A. Pidekso (ed.); 1st ed.). Andi Offset. 